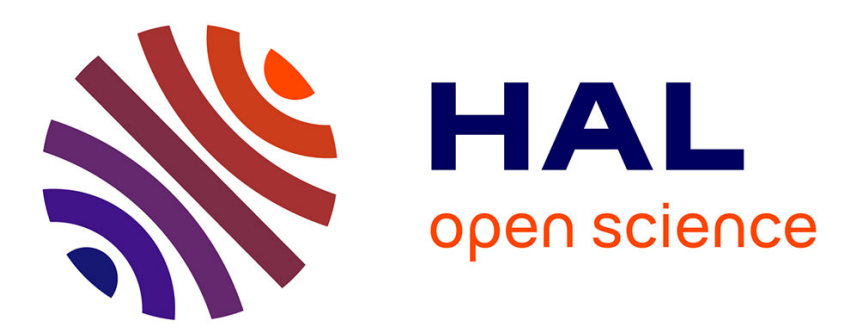

\title{
New psocids (Psocodea: Prionoglarididae, Psyllipsocidae) from Cretaceous Burmese amber deposits
}

Corentin Jouault, Kazunori Yoshizawa, Marina Hakim, Diying Huang, André $\mathrm{Nel}$

\section{To cite this version:}

Corentin Jouault, Kazunori Yoshizawa, Marina Hakim, Diying Huang, André Nel. New psocids (Psocodea: Prionoglarididae, Psyllipsocidae) from Cretaceous Burmese amber deposits. Cretaceous Research, 2021, 126, pp.104890. 10.1016/j.cretres.2021.104890 . insu-03227758

\section{HAL Id: insu-03227758 https://hal-insu.archives-ouvertes.fr/insu-03227758}

Submitted on 17 May 2021

HAL is a multi-disciplinary open access archive for the deposit and dissemination of scientific research documents, whether they are published or not. The documents may come from teaching and research institutions in France or abroad, or from public or private research centers.
L'archive ouverte pluridisciplinaire $\mathbf{H A L}$, est destinée au dépôt et à la diffusion de documents scientifiques de niveau recherche, publiés ou non, émanant des établissements d'enseignement et de recherche français ou étrangers, des laboratoires publics ou privés. 


\section{Journal Pre-proof}

New psocids (Psocodea: Prionoglarididae, Psyllipsocidae) from Cretaceous Burmese amber deposits

C.O.R.E.N.T.I.N. JOUAULT, K.A.Z.U.N.O.R.I. YOSHIZAWA, M.A.R.I.N.A. HAKIM, D.I.Y.I.N.G. HUANG, A.N.D.R.E. NEL

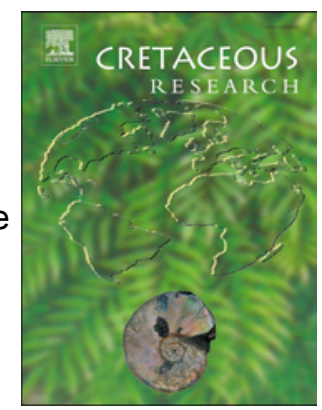

PII: S0195-6671(21)00137-3

DOI: https://doi.org/10.1016/j.cretres.2021.104890

Reference: $\quad$ YCRES 104890

To appear in: Cretaceous Research

Received Date: 17 February 2021

Revised Date: 12 April 2021

Accepted Date: 9 May 2021

Please cite this article as: JOUAULT, C., YOSHIZAWA, K., HAKIM, M., HUANG, D., NEL, A., New psocids (Psocodea: Prionoglarididae, Psyllipsocidae) from Cretaceous Burmese amber deposits, Cretaceous Research, https://doi.org/10.1016/j.cretres.2021.104890.

This is a PDF file of an article that has undergone enhancements after acceptance, such as the addition of a cover page and metadata, and formatting for readability, but it is not yet the definitive version of record. This version will undergo additional copyediting, typesetting and review before it is published in its final form, but we are providing this version to give early visibility of the article. Please note that, during the production process, errors may be discovered which could affect the content, and all legal disclaimers that apply to the journal pertain.

(c) 2021 Elsevier Ltd. All rights reserved. 
Toumal Pre-proo

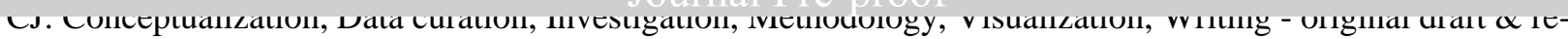
view. KY: Data curation, Investigation, Methodology, Writing - original draft \& review. MH: Data curation, Investigation, Methodology, Visualization, Writing review. DH: Data curation, Investigation, Methodology, Visualization. AN: Supervision, Data curation, Methodology, Investigation, Writing - original draft \& review. 
new psocias (rsocodea: rrionogiarıaiaae, rsyilpsociaae) Irom Cretaceous

\section{Burmese amber deposits}

CORENTIN JOUAULT ${ }^{1, *}$, KAZUNORI YOSHIZAWA ${ }^{2}$, MARINA HAKIM $^{3,4}$, DIYING

HUANG $^{3}$, ANDRE NEL $^{5}$

${ }^{1}$ Univ. Rennes, CNRS, Geosciences Rennes, UMR 6118, F-35000, Rennes, France. Email:

jouaultc0@gmail.com / https://orcid.org/0000-0002-3680-5172

${ }^{2}$ Systematic Entomology, School of Agriculture, Hokkaido University, Sapporo, Japan. Email:

psocid@res.agr.hokudai.ac.jp / https://orcid.org/0000-0001-6170-4296

${ }^{3}$ State Key Laboratory of Palaeobiology and Stratigraphy, Center for Excellence in Life and

Paleoenvironment, Nanjing Institute of Geology and Palaeontology, Chinese Academy of Sciences,

Nanjing 210008, People's Republic of China. Email: marina@nigpas.ac.cn; ORCID

https://orcid.org/0000-0003-4398-6140. Email: dyhuang@nigpas.ac.cn; $\quad$ ORCID

https://orcid.org/0000-0002-5637-4867

${ }^{4}$ University of Science and Technology of China, Hefei 230026, People's Republic of China.

${ }^{5}$ Institut de Systématique, Évolution, Biodiversité (ISYEB) Muséum national d'Histoire naturelle,

CNRS, Sorbonne Université, EPHE, Université des Antilles, CP50, 57 rue Cuvier 75005 Paris,

France. Email: anel@mnhn.fr / https://orcid.org/0000-0002-4241-7651

* Corresponding author

Abstract 
amber (ca. $110 \mathrm{Ma}$ ), together with Psyllipsocus myanmarensis sp. nov., the third fossil psyllipsocid species described from from Noije Bum Hill (ca. $98 \mathrm{Ma}$ ). Based on the current observations of Palaeosiamoglaris hkamtiensis sp. nov., we discuss the synapomorphic characters proposed to define the tribe Siamoglaridini. Palaeosiamoglaris hkamtiensis sp. nov. is, inter alia, characterized by the maxillary palpomere 3 ca. 0.66 time as long as maxillary palpomere 4 , the second anal vein concavity turned toward posterior wing margin in forewing, Sc reaching R1 nearly at middle of radial cell. The new species Psyllipsocus myanmarensis sp. nov. is, inter alia, characterized by antennae with 11 segments, the radial cell closed and six-angled, and the quadrangular pterostigma.

Key words: Insecta, Psocodea, Prionoglaridetae, Psyllipsocetae, Hkamti,

\section{Introduction}

The Psocodea ('Psocoptera' + Phthiraptera) is an order relatively well known in the fossil record with 31 families and 101 genera known to date (www.fossilworks.org), and with more than 10,000 valid extant species (Johnson et al., 2020). The Psocodea should have arose during the late Devonian according to the recent result obtained from phylogenomic analysis (Misof et al., 2014) but the oldest fossil of the clade namely Westphalopsocus pumilio Azar et al., 2013 (in Nel et al., 2013) is from the Moscovian (Late Carboniferous), with the Permian Zygopsocus permianus Tillyard, 1935 as second described oldest record (Nel et al., 2012), and a third undescribed Middle Permian fossil from China (pers. obs.). Recently, de Moya et al., (2020) proposed a time-calibrated phylogeny of the crown Psocodea and estimate their arisen to the early Jurassic (de Moya et al., 2020: fig. 1) which is much younger than been previously proposed (e.g., Misof et al. 2014; Johnson et al., 2018; Yoshizawa et al., 2019) and may result from the partial integration of the fossil record as calibration points. This Jurassic dating, at most, can only concern the crown group of the 


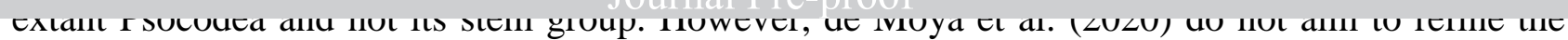
time divergence of the order but rather investigate the appearance of the parasitism in the Psocodea. Therefore, we should take into account that the age obtained is not for Psocodea arising but rather for parasitism appearance. If it would have concerned the total group, it would be incongruent with all the recently proposed phylogenetic placements of the Psocodea, either as sister group of the clade $($ Permopsocida $+($ Thripida + Hemiptera $)$ ), or as sister group of the Holometabola, both these clades being already present in the late Carboniferous (Nel et al., 2013; Huang et al., 2016). This gap between the time divergence estimates of the clade or some of its constitutive families (viz. the Liposcelididae) and their oldest representatives reflects, as for many other insect orders, the discrepancy between the fossil record and the time divergence estimate which mainly results from the poor integration of the fossil record.

The growing interest in the study of insects in Burmese amber leads to considerably increase the number of known psocid fossil species (e.g., Ross, 2019, 2020; Yoshizawa and Lienhard, 2020), with representatives of the families $†$ Archaeatropidae, Compsocidae, $†$ Cormopsocidae, Liposcelididae, Manicapsocidae, Pachytroctidae, Prionoglarididae, Psyllipsocidae, Sphaeropsocidae, and Trogiidae.

Herein it is described a new species of Palaeosiamoglaris Azar, Huang \& Nel, 2017 from Hkamti amber namely Palaeosiamoglaris hkamtiensis sp. nov., and the third fossil psyllipsocid species from Burmese amber namely Psyllipsocus myanmarensis sp. nov.

\section{Material and methods}

The amber pieces containing the specimens come from two Myanmar deposits, viz. Noije Bum and and Hkamti site. Noije Bum is in the Hukawng Valley $\left(26^{\circ} 29^{\prime} \mathrm{N}, 96^{\circ} 35^{\prime} \mathrm{E}\right)$, Kachin State, northern Myanmar (see detailed map in Grimaldi \& Ross, 2017: fig. 2). Radiometric data established an early Cenomanian age $(98.79 \pm 0.62 \mathrm{Ma})$ for Kachin amber, based on zircons from volcanic clasts found within the amber-bearing deposits (Shi et al. 2012). Some ammonites found in 


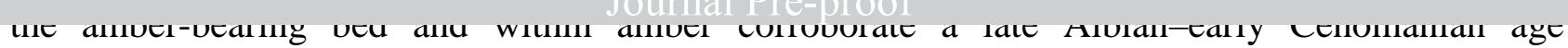

(Cruickshank and Ko, 2003; Yu et al., 2019). Hkamti site is located in the Hkamti District in the Sagaing Region, Myanmar (see detailed map in Xing \& Qiu, 2020: fig 1). Zircon U-Pb analyses established an early Albian age (109.7 $\pm 0.4 \mathrm{Ma})$ for Hkamti amber, based on zircon analyses of clastic sediments at the surface (Xing \& Qiu, 2020).

The two specimens are embedded in amber pieces of clear yellow amber. The amber pieces were polished to facilitate the observation of the specimens using a grinder polisher (Buehler EcoMet 30) with very thin silicon carbide sanding paper (grit size $=7000$ ). The specimens were examined and photographed with a Leica MZ APO with an attached Canon EOS 5D Mark II camera, a Zeiss AXIO Zoom V16 stereo microscope and a Zeiss AXIO Imager Z2 compound microscope equipped with fluorescence laser. All images are digitally stacked photomicrographic composites of several individual focal planes, which were obtained using HeliconFocus 6.7. The figures were composed with Adobe Illustrator CC2019 and Photoshop CC2019 softwares. We follow the wing venation nomenclature of Yoshizawa and Lienhard (2020) for the 'Psocoptera'.

Abbreviations. A for anal vein, $\mathrm{CuA} / \mathrm{P}$, cubitus anterior/posterior; M, median vein; R, radius; Rs radial sector posterior; Sc and Sc' basal and distal parts of subcostal vein respectively.

Published work and nomenclatural acts are registered in ZooBank (http://www.zoobank.org/, last access: 11 April 2021), with the following LSID (reference): urn:lsid:zoobank.org:pub:4A98BBB92223-4BC9-B285-04717B5F57EB

3. Systematic paleontology

Suborder Trogiomorpha Roesler, 1940

Infraorder Prionoglaridetae Smithers, 1972

Family Prionoglarididae Karny, 1930

Subfamily Prionoglaridinae Karny, 1930 


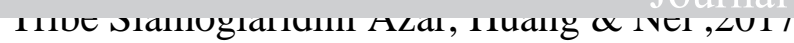

Genus Palaeosiamoglaris Azar, Huang \& Nel, 2017

Included species: P. lienhardi Azar, Huang \& Nel., 2017 (type species), P. burmica Azar, Huang \& Nel., 2017, P. inexpectata Azar, Huang \& Nel., 2017, and Palaeosiamoglaris hkamtiensis sp. nov.

Palaeosiamoglaris hkamtiensis sp. nov.

(Figs 1-2)

urn:1sid:zoobank.org:act:F35A5676-1574-4422-834C-A3D64F1335DB

Etymology: Named after the originating deposit of the amber piece, Hkamti. The specific epithet is to be treated as a feminine adjective.

Holotype: IGR.BU-022, deposited in the Geological Department and Museum of the University of Rennes, France (IGR) (in a piece of amber measuring $12 \times 7 \times 2 \mathrm{~mm}$ ).

Type locality: Hkamti site, Hkamti District, Sagaing Region, Myanmar.

Type horizon: Lower Albian (ca. $110 \mathrm{Ma}$ ), Lower Cretaceous.

Material. Holotype only.

Diagnosis. Maxillary palpomere 3 longer than half of palpomere 4 (ca. 0.66-time length of P4); Second anal vein concavity turned toward posterior wing margin in forewing; Sc reaching R1 nearly at middle of radial cell.

Description. Winged (maybe male). Body $2.05 \mathrm{~mm}$ long. Head much longer than wide in frontal view, triangular-shaped; ocelli present but not conspicuous; compound eye ovoid, without color pattern, ca. $0.21 \mathrm{~mm}$ long; antenna with 18 antennomeres (hardly visible due to amber), at least $1.85 \mathrm{~mm}$ long; several flagellomeres with annulate sculpture weakly visible but present; scape (ca. $0.155 \mathrm{~mm}$ long) less than twice as long as pedicel ( $c a .0 .095 \mathrm{~mm}$ long); scape slightly wider than pedicel; frontal suture present; clypeus conspicuous; labrum thin covering mandibles in frontal view; distal margin of labrum with placoids, (maybe containing a very short conical sensillum); maxillary palps four-segmented, $c a .0 .768 \mathrm{~mm}$ long; palpomeres respectively (from base to tip) 
slightly widened apically; labial palps two-segmented, not well-preserved. Thorax $c a .0 .60 \mathrm{~mm}$ long. Legs with tibiae with minute, strong spines; tarsi three-segmented, basal tarsomere the longest and apical one the shortest; tarsal claws asymmetrical, with preapical tooth, membranous extension of anterior preapical claws strongly developed. Forewing hyaline, glabrous, $c a .2 .66 \mathrm{~mm}$ long, $c a$. $1.31 \mathrm{~mm}$ wide, with pterostigma not colored; wing apex broadly rounded; complete venation; Sc long, with its basal part strongly curved, distally fused with R1 in the middle of radial cell; Sc' straight, reaching wing margin at $1.87 \mathrm{~mm}$ from wing base and closing pterostigma; base of last R1 section separated from base of Sc' by a small section of R1; R1 reaching costal margin $2.15 \mathrm{~mm}$ from wing base; Rs bifurcating into $\mathrm{R} 2+3$ and $\mathrm{R} 4+5$ at $1.93 \mathrm{~mm}$ distal of wing base; $\mathrm{R} 2+3$ reaching wing margin at $2.46 \mathrm{~mm}$; R4+5 slightly curved to straight, reaching wing margin at $2.66 \mathrm{~mm}$; radial cell closed, heptagonal, longer than wide; M1+M2 bifurcating into M1 and M2 at $2.03 \mathrm{~mm}$ from wing base; M1 and M2 reaching wing margin respectively at $2.67 \mathrm{~mm}$ and $2.51 \mathrm{~mm}$; M3 bifurcating from $\mathrm{M}$ at $1.84 \mathrm{~mm}$ and reaching wing margin at $2.24 \mathrm{~mm}$; fork of $\mathrm{CuA}$ in $\mathrm{CuA} 1$ and $\mathrm{CuA} 21.24 \mathrm{~mm}$ from wing base; CuA1 strongly curved and longer than $\mathrm{CuA} 2$, reaching wing margin at $1.87 \mathrm{~mm}$; $\mathrm{CuA} 2$ straight to slightly curved, reaching wing margin at $1.53 \mathrm{~mm}$; areola postica (AP) free; CuP straight, joining anal vein at posterior wing margin in a nodulus at $1.19 \mathrm{~mm}$ from wing base; A2 curved, joining wing margin at $0.57 \mathrm{~mm}$ with concavity directed toward wing base. Hind wing, hyaline, normally developed with complete venation, smaller than forewing, $c a$. $2.00 \mathrm{~mm}$ long and at least $0.64 \mathrm{~mm}$ wide; Sc short and ending free in membrane; R1 reaching costal margin at $1.31 \mathrm{~mm}$ from wing base; Rs fused with $\mathrm{M}$ for a short distance; Rs bifurcating into R2+3 and $\mathrm{R} 4+5$ at $1.67 \mathrm{~mm}$ apically; $\mathrm{R} 2+3$ and $\mathrm{R} 4+5$ reaching wing margin respectively at 1.74 and 2.01 $\mathrm{mm}$; M bifurcating into M1 and M2 at $1.39 \mathrm{~mm}$ from wing base; M1 and M2 reaching wing margin respectively at 1.87 and $1.64 \mathrm{~mm}$; CuA slightly curved medially, reaching wing margin at $1.33 \mathrm{~mm}$ apically; CuP reaching wing margin at $1.10 \mathrm{~mm}$; A bifurcated into A1 and A2 respectively reaching 
much damaged to be described.

Remark. The new species also differs from its relatives in its age (ca. $110 \mathrm{Ma}$ vs. $98 \mathrm{Ma}$ ).

Infraorder Psyllipsocetae Smithers, 1972

Family Psyllipsocidae Kolbe, 1884

See detailed list of genera and species in Lienhard and Smithers (2002), Hakim et al. (2018) with the addition of Wang et al. (2019) and Álvarez-Parra et al. (2020).

Genus Psyllipsocus Selys-Longchamps, 1872

Psyllipsocus myanmarensis sp. nov.

Figures 3-6

urn:lsid:zoobank.org:act:3DF220F8-4693-4049-8CFE-9F2908002494

Etymology: Named after the originating country of the amber piece, Myanmar. The specific epithet is to be treated as a masculine adjective.

Holotype: IGR.BU-023 (female), deposited in Geological Department and Museum of the

University of Rennes, France (IGR) (in a piece of amber measuring $11 \times 5 \times 2 \mathrm{~mm}$ ); Paratype

NIGP174915 (male) deposited in the Nanjing Institute of Geology and Palaeontology, Chinese Academy of Science, China (NIGP).

Type locality: Noije Bum Hill, Hukawng Valley, Kachin State, Myanmar.

Type horizon: upper Albian to lower Cenomanian (ca.98 Ma), mid-Cretaceous.

Material. Holotype only.

Diagnosis. Antenna with 11 antennomeres; forewing with complete venation, sparse setation on veins; radial cell closed, six-angled; crossvein R1-Rs clearly separated from base of Sc', leading in an hexagonal radial cell; quadrangular pterostigma; Rs and $\mathrm{CuA}$ branched; elongated areola postica; 


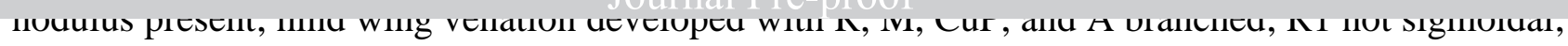

legs with three-segmented tarsi.

Description. Female winged. Body ca. $1.25 \mathrm{~mm}$ long. Head as long as wide in frontal view (when eyes are included), triangular-shaped; vertex broad with ratio (distance between compound eyes/greatest width of postclypeus) $=1.47$; ocelli arranged as an isosceles triangle with greatest distance between lateral ocelli; compound eye ovoid, without color pattern, ca. $0.12 \mathrm{~mm}$ long; antennal socket with a dorsal ridge; antennae with 11 antennomeres, $c a .0 .8 \mathrm{~mm}$ long; scape and pedicel of nearly same lengths, $c a$. $0.077 \mathrm{~mm}$ long, both of similar width; first flagellomere $c a$. $0.088 \mathrm{~mm}$ long; second flagellomere the longest, $c a .0 .10 \mathrm{~mm}$ long, remaining ones decreasing in length toward apex with apical most flagellomere the smallest; frontal suture present; clypeus massive, bulging from head; labrum thin, covering mandibles in frontal view; maxillary palps foursegmented, $c a$. $0.30 \mathrm{~mm}$ long; palpomeres respectively (from base to tip) $0.039,0.100,0.050,0.111$ mm long, with second one lacking conical sensillum, and apical one slightly drop shape; labial palps two-segmented, terminal palpomere elongate with its length much more than twice its width. Thorax $0.440 \mathrm{~mm}$ long. Tibiae with minute strong spines; tarsi three-segmented, basal tarsomere the longest and middle one the shortest; preapical claws symmetrical, simple (viz. without preapical tooth). Forewing hyaline, with sparse setation on veins, $c a .1 .30 \mathrm{~mm}$ long, $c a .0 .45 \mathrm{~mm}$ wide, with pterostigma not particularly colored; wing apex rounded; complete venation; Sc short and not reaching $\mathrm{R}$ or wing margin but ending free in membrane; Sc' reaching wing margin at $0.69 \mathrm{~mm}$ from wing base and closing pterostigma; base of last R1 section separated from base of Sc' by a small section of R1; R1-Rs crossvein clearly separated from base of Sc'; R1 reaching costal margin $0.95 \mathrm{~mm}$ from wing base; Rs fused with $\mathrm{M}$ basally for a short distance; Rs bifurcating into R2+3 and $\mathrm{R} 4+5$ at $0.92 \mathrm{~mm}$ distal of wing base; R2+3 reaching wing margin at $1.09 \mathrm{~mm}$; R4+5 slightly curved to straight, reaching wing margin at $1.17 \mathrm{~mm}$; radial cell closed, hexagonal, with lateral sides the longest; M1+M2 bifurcating into M1 and M2 at $1.04 \mathrm{~mm}$ from wing base; M1 and M2 reaching wing margin respectively at $1.23 \mathrm{~mm}$ and $1.21 \mathrm{~mm}$; $\mathrm{M} 3$ bifurcating from $\mathrm{M}$ at $0.90 \mathrm{~mm}$ 
$\mathrm{CuA} 1$ gently curved and longer than $\mathrm{CuA} 2$, reaching wing margin at $1.01 \mathrm{~mm}$; $\mathrm{CuA} 2$ curved, reaching wing margin at $0.73 \mathrm{~mm}$; areola postica $(\mathrm{AP})$ free and elongate; CuP slightly curved medially, joining anal vein at posterior wing margin in a nodulus at $0.55 \mathrm{~mm}$ from wing base. Hind wing, hyaline, normally developed with complete venation, $1.19 \mathrm{~mm}$ long and at least $0.32 \mathrm{~mm}$ wide; Sc very short and ending free in membrane; $\mathrm{R} 1$ reaching costal margin at $0.76 \mathrm{~mm}$ from wing base; Rs fused with $\mathrm{M}$ for a distance; Rs bifurcating into $\mathrm{R} 2+3$ and $\mathrm{R} 4+5$ at $1.01 \mathrm{~mm}$ apically; $\mathrm{R} 2+3$ and $\mathrm{R} 4+5$ reaching wing margin respectively at 1.13 and $1.18 \mathrm{~mm}$; M bifurcating into M1 and $\mathrm{M} 2$ at $0.76 \mathrm{~mm}$ from wing base; $\mathrm{M} 1$ and $\mathrm{M} 2$ reaching wing margin respectively at 1.08 and $0.86 \mathrm{~mm}$; CuA curved, reaching wing margin at $0.61 \mathrm{~mm}$ apically; $\mathrm{CuP}$ very slightly curved, reaching wing margin at $0.45 \mathrm{~mm}$; A bifurcated into A1 and A2 (wing membrane folded due to preservation). Abdomen ca. $0.65 \mathrm{~mm}$ long (including genitalia). Female genitalia with subgenital plate pointed apically, short, half-length of rounded and setose external valvula of gonapophyses, thin ventral valvula; dorsal valvula not discernable; paraprocts elongate, pointed apically.

Male genitalia setose, hypandrium simple with rounded posterior margin, parameres broad and well developed, trichobothrial field on paraprocts well developed.

Remarks: The reduced number of antennomeres is a unique feature among all known Psyllipsocidae. We can ensure this number based on three observations: (1) all the antennomeres shorten in length towards the apex, (2) the apical flagellomere does not present a hole at the apex allowing the insertion of an additional segment, and (3) the apex gradually becomes thinner, and is rounded. Additionally, this unique character is found on several specimens refuting the possibility that this condition represents abnormality.

\section{Discussion}

Several previous publications justified the family attributions of some fossils based only or mainly on the key of Smithers (1990), but several issues point off concerning this method: this key is an 


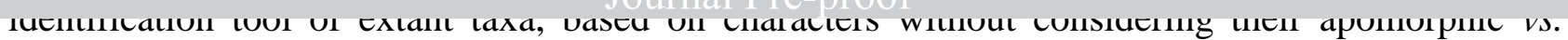

plesiomorphic states. It would be more accurate to base our placements on the recent higher classification system of Trogiomorpha (Yoshizawa et al., 2006; Yoshizawa and Lienhard, 2020) defining several female synapomorphic characters supporting the Trogiomorpha: ventral and dorsal valves of gonapophyses strongly reduced or absent, external valves well-developed and setose; subgenital plate short, covering at most basal part of external valves, which come close to ventral midline of abdomen, forming the ovipositor. However, these characters are not available in the holotype of Palaeosiamoglaris hkamtiensis sp. nov.

Recently, the tribe Siamoglaridini was erected based on fossil and extant species (Azar et al., 2017) and placed among the Trogiomorpha. If the synapomorphic characters used to define the suborder are not all recorded in the Siamoglaridini (e.g. the ventral valves of gonapophyses strongly reduced), its assignment to the subfamily Prionoglaridinae is obviously supported by the following apomorphies: long antennae composed of at most 13 flagellomeres and broadened and rounded forewing (apomorphies for the family Prionoglarididae), adult lacinia reduced, asymmetric pretarsal claws, anterior claw with membranous extension, and phallosome consisting of cuticular sac with pair of posterolateral processes (apomorphies for the subfamily Prionoglaridinae) (Yoshizawa et al., 2006; Yoshizawa and Lienhard, 2020). Monophyly of Trogiomorpha including Prionoglarididae is well supported morphologically and molecularly (Yoshizawa et al., 2006; Johnson et al., 2018; Yoshizawa and Lienhard, 2020; de Moya et al., 2020) so that there is no doubt about the placement of Siamoglaridini within the suborder Trogiomorpha.

Palaeosiamoglaris hkamtiensis sp. nov. is placed among the Siamoglaridini and among the genus Palaeosiamoglaris (see below) since it fits with the diagnosis of the tribe in having distal margin of labrum with placoids; legs lacking trichobothria; pretarsal claws asymmetric, lacking preapical tooth; forewing with pterostigma slightly opaque (difficult to observe due to amber preservation) and second anal vein A2 present. However, Palaeosiamoglaris hkamtiensis sp. nov. would differ from the other Siamoglaridini in having compound eyes with apparently uniform color 


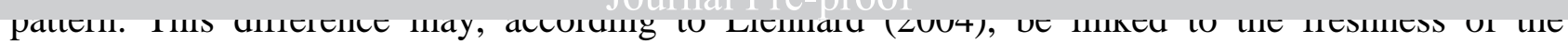

specimen and therefore be lost if it took a long time to have it embedded in the resin. It should not be considered as a diagnostic character to exclude Palaeosiamoglaris hkamtiensis sp. nov. from the tribe. According to the datation of Hkamti amber deposit (ca. $110 \mathrm{Ma}$; Xing and Qiu, 2020), Palaeosiamoglaris hkamtiensis sp. nov. is the oldest Prionoglarididae. Following the description of Azar et al. (2017), Palaeosiamoglaris hkamtiensis sp. nov. fits with the diagnostic characters of Palaeosiamoglaris in having maxillary palp much longer than half of head length; maxillary palp 3 (P3) longer than half of maxillary palp 4 (P4); terminal labial palpomere elongate, with its length much more than twice its width.

Palaeosiamoglaris hkamtiensis sp. nov. differs from P. lienhardi in having P3 longer than $\mathrm{P} 4$ half length ( $\mathrm{P} 3 \mathrm{ca} .0 .66$ times $\mathrm{P} 4$ vs. 0.49 in $P$. lienhardi); $\mathrm{Sc}$ reaching $\mathrm{R} 1$ at middle of radial cell (vs. more distally). It also differs from $P$. burmica in having $\mathrm{P} 3$ proportionally longer (P3 $c a .0 .66$ times $\mathrm{P} 4$ vs. 0.59 in $P$. burmica) Sc reaching $\mathrm{R} 1$ at middle of radial cell (vs. more basally). Palaeosiamoglaris hkamtiensis sp. nov. differs from P. inexpectata in having P3 longer than P4 half length (vs. P3 more than twice as long as P4); Sc reaching $\mathrm{R}$ in $\mathrm{R} 1$ at middle of radial cell (vs. reaching $\mathrm{R}$ basally of the radial cell), $\mathrm{CuA} 1$ gently curved and not converging toward $\mathrm{CuA} 2$.

Psyllipsocus myanmarensis sp. nov. has all the synapomorphic characters supporting the Trogiomorpha (viz. ventral valvula of gonapophyses very thin, dorsal valvula strongly reduced or absent, external valvula well-developed and setose; subgenital plate short, half-length of external valves, which come close to ventral midline of abdomen, forming the ovipositor). Psyllipsocus myanmarensis sp. nov. is assigned to the Psyllipsocetae and to the family Psyllipsocidae but the autapomorphy proposed to define the infraorder: spermathecal sac lacking glandular accessory bodies, with complicated sclerifications at origin of duct and often with accessory vesicle (Yoshizawa et al. 2006), cannot be observed in our specimen due to the preservation in amber. However, Psyllipsocus myanmarensis sp. nov. has the additional characters proposed to define the infraorder, viz. the second maxillary palpomere without conical spur sensillum; basal segment of 


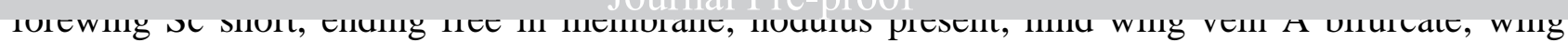

pilosity developed (partially preserved on our specimen); female external valve of gonapophyses broad.

To date, there are three psyllipsocid genera described from Burmese amber, namely Annulipsyllipsocus Hakim et al., 2017 (two species: Hakim et al., 2017), Concavapsocus Wang et al., 2019 (one species: Wang et al., 2019) and Psyllipsocus yoshizawai Álvarez-Parra et al., 2020. Psyllipsocus myanmarensis sp. nov. differs from Annulipsyllipsocus in lacking secondary annulations of antennomeres, in having a longer pterostigma and a hexagonal radial cell, R1-Rs crossvein clearly separated from base of Sc', and an elongated areola postica. It differs from Concavapsocus in the forewing venation complete, with radial cell closed (vs. reduced and opened), $\mathrm{M}$ forked with three section (vs. simple), CuA1 forked (vs. simple), nodulus present; hind wing with $\mathrm{R}$ forked (vs. simple), $\mathrm{M}$ forked with two section (vs. simple), $\mathrm{CuA}$ and $\mathrm{CuP}$ both present (vs. $\mathrm{CuP}$ absent), A bifurcated (vs. absent). In fact, the wing venation of Concavapsocus is completely different from those of all Psyllipsocidae and probably does not belong to this family (Dany Azar pers. comm.).

The extant and fossil genus Psyllipsocus Selys-Longchamps, 1872 shows a high disparity in the wing venation, with or without radial cell, Sc', etc. (Mockford, 2011; Lienhard and Ferreira, 2013, 2014; Lienhard and García-Aldrete, 2016). Psyllipsocus is characterized by a broad vertex, with ratio (distance between compound eyes/greatest width of postclypeus) $=1.41$ or more (Mockford, 1993: 52); which is the case for Psyllipsocus myanmarensis sp. nov.

Psyllipsocus myanmarensis sp. nov. has a forewing venation rather similar to that of the third Burmese amber Psyllipsocidae (P. yoshizawai) but it differs in the forewing veins $\mathrm{R} 2+3, \mathrm{R} 4+5$ and M3 longer, the hind wing vein R1 simply curved vs. sigmoidal, veins M1 and M2 distinctly longer, M2 having a different orientation (Álvarez-Parra et al., 2020: fig. 2), and in the number of antennomeres (11 vs. at least 16). 
genus Khatangia Vishniakova, 1975 since having a hexagonal radial cell (vs. pentagonal) and a long and wide triangular pterostigma (vs. short and quadrangular) (Vishniakova, 1975: figs 7-14). Additionally, the genus Khatangia lacks the nodulus in forewing (i.e. $\mathrm{CuP}$ and $\mathrm{A}$ reaching wing margin separately; see Vishynakova, 1975) while representatives of the genus Psyllipsocus have a nodulus.

Psyllipsocus myanmarensis sp. nov. also differs from the extant genus Pseudopsyllipsocus Li, 2002 in having female fully winged (vs. apterous) and claws simple (vs. with a preapical tooth) (Li, 2002: 58 \& 1766). Psyllipsocus myanmarensis sp. nov. cannot be placed in the extant genera Dorypteryx Aaron, 1883, Psocathropos Ribaga, 1899, and Pseudorypteryx García-Aldrete, 1984 since having normal wing with complete venation (vs. narrow elongate wings with a reduced venation) (GarcíaAldrete, 1984; Li and Liu, 2009; Lienhard and Ferreira, 2015).

\section{Conclusions}

The new fossils demonstrate that the Prionoglarididae are rather an old group existing at least from the Albian (Lower Cretaceous) with a diversity surely underestimated in fossil ages. Similarly, Psyllipsocus myanmarensis sp. nov. by displaying a unique wing venation for Cretaceous Psyllipsocidae and a striking reduction of the number of antennomeres highlights the underestimated diversity of the family during the Cretaceous. This unprecedented number of antennomeres (unknown in extant Psyllipsocidae) surely indicates a peculiar biology and behavior. It is possibly an adaptation to a special ecological niche. Therefore, Psyllipsocus myanmarensis sp. nov. highlights also the underestimated ecological diversity of this family during the Cretaceous. Recently, numerous phylogenetic analyses have been proposed for the Psocodea but none fully integrates the information from the fossil record resulting in underestimated time divergence for the constitutive families. It would be interesting to propose a total-evidence dating or tip-dating 


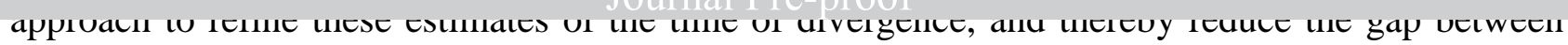
fossil data and molecular clocks.

\section{Acknowledgments}

This work was supported by the Japan Society for the Promotion of Science under Grant (19H03278). Financial support was also partially provided by the Strategic Priority Research Program of the Chinese Academy of Sciences (XDB26000000 and XDB18000000) and the National Natural Science Foundation of China (41688103). We are grateful to Prof. Dany Azar and an anonymous reviewer for insightful comments on the manuscript. We thank the editor (Dr. Eduardo Koutsoukos) for his suggestions on the manuscript.

\section{References}

Álvarez-Parra, S., Peñalver, E., Nel, A., Delclòs, X., 2020. The oldest representative of the extant barklice genus Psyllipsocus (Psocodea: Trogiomorpha: Psyllipsocidae) from the Cenomanian amber of Myanmar. Cretaceous Research 113, 1-9. https://doi.org/10.1016/j.cretres.2020.104480

Azar, D., Huang, D.-y., El-Hajj, L., Cai, C., Nel, A., Maksoud, S., 2017. New Prionoglarididae from Burmese amber (Psocodea: Trogiomorpha: Prionoglaridetae). Cretaceous Research 75, 146-156. https://doi.org/10.1016/j.cretres.2017.03.028

Cruickshank, R.D., Ko, K., 2003. Geology of an amber locality in the Hukawng Valley, northern Myanmar. Journal of Asian Earth Sciences 21, 441-455. https://doi.org/10.1016/S13679120(02)00044-5

de Moya, R.S., Yoshizawa, K., Walden, K.K.O., Sweet, A.D., Dietrich, C.H., Johnson, K.P., 2020. Phylogenomics of parasitic and non-parasitic lice (Insecta: Psocodea): combining sequence data and exploring compositional bias solutions in Next Generation Datasets. Systematic Biology syaa075. https://doi.org/10.1093/sysbio/syaa075 


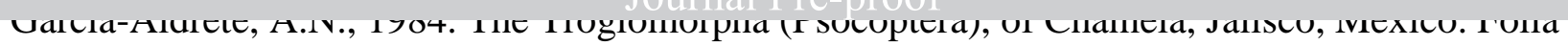

Entomologica Mexicana 59, 25-69.

Grimaldi, D., Ross, A., 2017. Extraordinary lagerstätten in amber, with particular reference to the Cretaceous of Burma. In: Fraser N.C., and Sues H.-D. (Eds.), Terrestrial conservation lagerstätten: Windows into the evolution of life on land. Edinburgh (SC): Dunedin Academic Press. p. 287-342.

Hakim, M., Azar, S., Maksoud, S., Huang, D.-y., Azar, D., 2018. New polymorphic psyllipsocids from Burmese amber (Psocodea: Psyllipsocidae). Cretaceous Research 84, 389-400. https://doi.org/10.1016/j.cretres.2017.11.027

Huang, D.-y., Bechly, G., Nel, P., Engel, M.S., Prokop, J., Azar, D., Cai, C.-Y., van de Kamp, T., Staniczek, A.H., Garrouste, R., Krogmann, L., dos Santos Rolo, T., Baumbach, T., Ohlhoff, R., Shmakov, A.S., Bourgoin, T., Nel A., 2016. New fossil insect order Permopsocida elucidates major radiation and evolution of suction feeding in hemimetabolous insects (Hexapoda: Acercaria). Scientific Reports 6, 1-9. https://doi.org/10.1038/srep23004

Johnson, K.P., Smith, V.S., Hopkins, H., Eades, D.C., 2020. SF Psocodea: Psocodea Species File (version 5.0, Jun 2018). In: Species 2000 \& ITIS Catalogue of Life, 2020-09-01 Beta (Roskov, Y., Ower, G., Orrell, T., Nicolson, D., Bailly, N., Kirk, P.M., Bourgoin, T., DeWalt, R.E., Decock, W., van Nieukerken, E., Penev, L., eds.). Digital resource at www.catalogueoflife.org/col. Species 2000: Naturalis, Leiden, the Netherlands. ISSN 24058858.

Li, F,. 2002. Psocoptera of China. Geijing: Huayu Nature Book Trade Co.Ltd

Li, F., Liu, X., 2009. Discovery in China of Dorypteryx Aaron (Psocoptera: Trogiomorpha: Psyllipsocidae), with one new species. Zootaxa 1983, 63-65. https://doi.org/10.11646/zootaxa.1983.1.5

Lienhard, C., 1998. Psocoptères euro-méditerranéens. Paris: Fédération Française des Sociétés de Sciences Naturelles. 
from the Oriental (Sino-Indian) region (Insecta: Psocoptera). Revue suisse de Zoologie 111, 865-875. https://doi.org/10.5962/bhl.part.80272

Lienhard, C., Ferreira, R.L., 2013. Three new species of Psyllipsocus (Psocodea: 'Psocoptera': Psyllipsocidae) from Brazilian caves with description of a novel structure interpreted as a male accessory genital organ. Revue suisse de Zoologie 120, 421-443. https://www.biodiversitylibrary.org/page/50420516

Lienhard, C., Ferreira, R.L., 2014. New species of Psyllipsocus from Brazilian caves (Psocodea: 'Psocoptera': Psyllipsocidae). Revue suisse de Zoologie 121, 211-246.

Lienhard, C., Ferreira, R.L., 2015. Review of Brazilian cave psocids of the families Psyllipsocidae and Prionoglarididae (Psocodea: 'Psocoptera': Trogiomorpha) with a key to the South American species of these families. Revue suisse de Zoologie 122, 121-142. https://doi.org/10.5281/zenodo.14579

Lienhard, C., García Aldrete, A.N., 2016. An extraordinary new species of Psyllipsocus (Psocodea: 'Psocoptera': Psyllipsocidae) from the Biosphere Reserve Sierra de Huautla, Morelos, Mexico. Revue suisse de Zoologie 123, 105-112. https://doi.org/10.5281/zenodo.46291

Lienhard, C., Smithers, C.N., 2002. Psocoptera (Insecta): World catalogue and bibliography. Genève (GE): Muséum d'histoire naturelle, pp 745.

Misof, B., Liu, S., Meusemann, K., Peters, R.S., Donath, A., Mayer, C., Frandsen, P.B., Ware, J., Flouri, T., Beutel, R.G., et al. 2014. Phylogenomics resolves the timing and pattern of insect evolution. Science 346, 763-767. https://doi.org/10.1126/science.1257570

Mockford, E.L., 1993. North American Psocoptera (Insecta). New York (NY): CRC Press. Mockford, E.L., 2011. New species of Psyllipsocus (Psocoptera: Psyllipsocidae) from North and Middle America with a key to the species of the region. Transactions of the American Entomological Society 137, 15-47. https://www.jstor.org/stable/41495851 


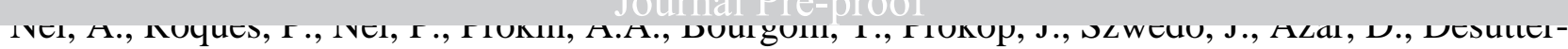

Grandcolas, L., Wappler, T., Garrouste, R., Coty, D., Huang, D.-y., Engel, M.S., Kirejtshuk, A.G., 2013. The earliest known holometabolous insects. Nature 503, 257-261. https://doi.org/10.1038/nature12629

Ross, A.J., 2019. Burmese (Myanmar) amber checklist and bibliography 2018. Palaeoentomology 2, 22-84. https://doi.org/10.11646/palaeoentomology.2.1.5

Shi, G.H., Grimaldi, D.A., Harlow, G.E., Wang, J., Yang, M., Lei, W., Li, Q., Li, X., 2012. Age constraint on Burmese amber based on U-Pb dating of zircons. Cretaceous Research 37, 155163. https://doi.org/10.1016/j.cretres.2012.03.014

Smithers, C.N., 1972. The classification and phylogeny of Psocoptera. Australian Museum Memoir 14, 1-351. https://doi.org/10.3853/j.0067-1967.14.1972.424

Smithers, C.N., 1990. Keys to the families and genera of Psocoptera (Arthropoda, Insecta).Technical Reports of the Australian Museum 2, 1-82. https://doi.org/10.3853/j.10318062.2.1990.77

Vishniakova, V.N., 1975. Psocoptera in Late-Cretaceous insect-bearing resins from the Taimyr. Entomological Review 54, 63-75.

Wang, R.Q., Li, S., Ren, D., Yao, Y.Z., 2019. New genus and species of the Psyllipsocidae (Psocodea: Trogiomorpha) from mid-Cretaceous Burmese amber. Cretaceous Research 104, 104178. https://doi.org/10.1016/j.cretres.2019.07.008

Xing, L., Qiu, L., 2020. Zircon U-Pb age constraints on the mid-cretaceous Hkamti amber biota in northern Myanmar. Palaeogeography, Palaeoclimatology, Palaeoecology 109960. https://doi.org/10.1016/j.palaeo.2020.109960

Yoshizawa, K., Lienhard, C., 2020. †Cormopsocidae: A new family of the suborder Trogiomorpha (Insecta: Psocodea) from Burmese amber. Entomological Science 23, 208-215. https://doi.org/10.1111/ens.12414 


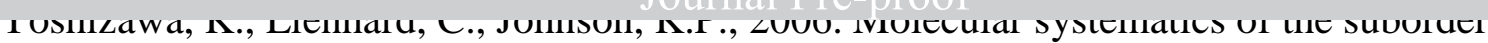

Trogiomorpha (Insecta: Psocodea: "Psocoptera"). Zoological Journal of the Linnean Society 146, 287-299. https://doi.org/10.1111/j.1096-3642.2006.00207.x

Yoshizawa, K., Lienhard, C., Yao, I., Ferreira, R.L., 2019. Cave insects with sex-reversed genitalia had their most recent common ancestor in West Gondwana (Psocodea: Prionoglarididae: Speleketorinae). Entomological Science 22, 334-338. https://doi.org/10.1111/ens.12374 Yu, T., Kelly, R., Mu, L., Ross, A., Kennedy, J., Broly, P., Xia, F., Zhang, H., Wang, B., Dilcher, D., 2019. An ammonite trapped in Burmese amber. Proceedings of the National Academy of Sciences 116, 11345-11350. https://doi.org/10.1073/pnas.1821292116

\section{FIGURE CAPTIONS}

Fig. 1. Palaeosiamoglaris hkamtiensis sp. nov., holotype IGR.BU-022 (female). Habitus in ventrolateral view. Scale bar: $0.5 \mathrm{~mm}$.

Fig. 2. Palaeosiamoglaris hkamtiensis sp. nov., holotype IGR.BU-022 (female). A: Detailed view of mouthparts (arrow pointing labrum and location of placoids). B: Wing venation. C: Antenna. D: Detailed view of hind tarsus. E: Labelled line drawing of wings venation. F: Line drawing of distal part of tarsus with pretarsal claws. Scale bars $0.5 \mathrm{~mm}(\mathrm{~A}, \mathrm{~B}, \mathrm{C}, \mathrm{D}, \mathrm{E}), 0.03 \mathrm{~mm}(\mathrm{~F})$

Fig. 3. Psyllipsocus myanmarensis sp. nov., holotype IGR.BU-023. Habitus in right-lateral view. Scale bar $0.5 \mathrm{~mm}$. 


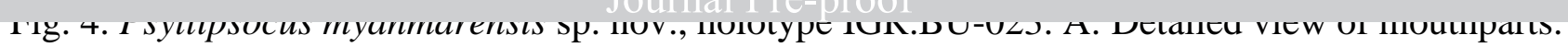
B: Detailed view of left antenna. C: Detailed view of wing venation. D: Labelled line drawing of wing venation. Scale bars $0.25 \mathrm{~mm}$.

Fig. 5. Psyllipsocus myanmarensis sp. nov., paratype NIGP174915 (male). Habitus in frontal view. Scale bar $0.2 \mathrm{~mm}$.

Fig. 6. Psyllipsocus myanmarensis sp. nov., paratype NIGP174915 (male). A: Detailed view of head in frontal view. B: Head in full face view. C: Detailed view of fore tarsus. D: Apical part of abdomen. E: Forewing. F: Labelled line drawing of forewing venation. G: Hind wing. H: Labelled line drawing of forewing venation. Scale bars $0.1 \mathrm{~mm}(\mathrm{~A}, \mathrm{D}) ; 0.2 \mathrm{~mm}(\mathrm{~B}, \mathrm{~F}, \mathrm{H}) ; 0.02$ $\mathrm{mm}(\mathrm{C}) ; 0.5 \mathrm{~mm}(\mathrm{E}, \mathrm{G})$. 


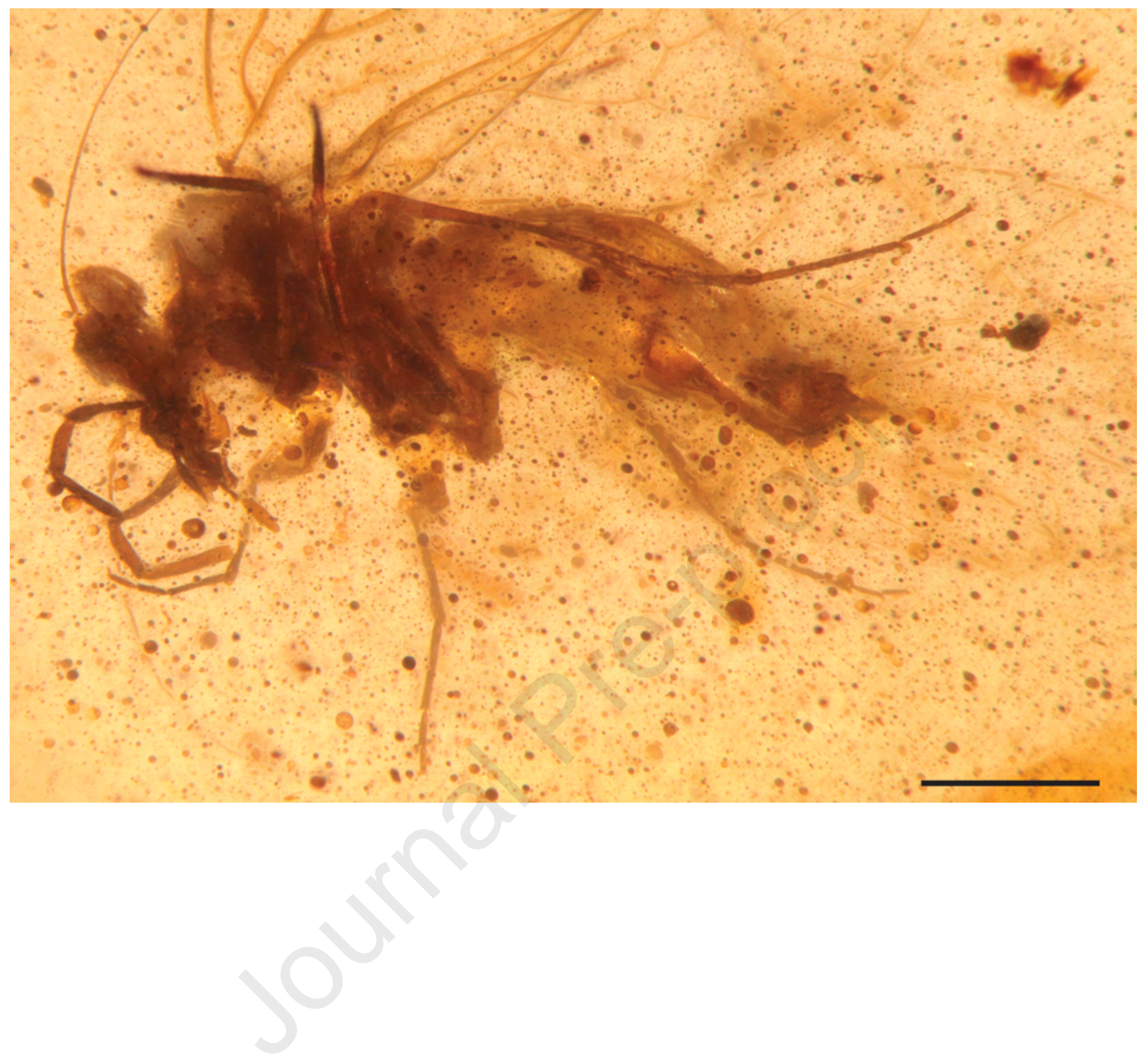




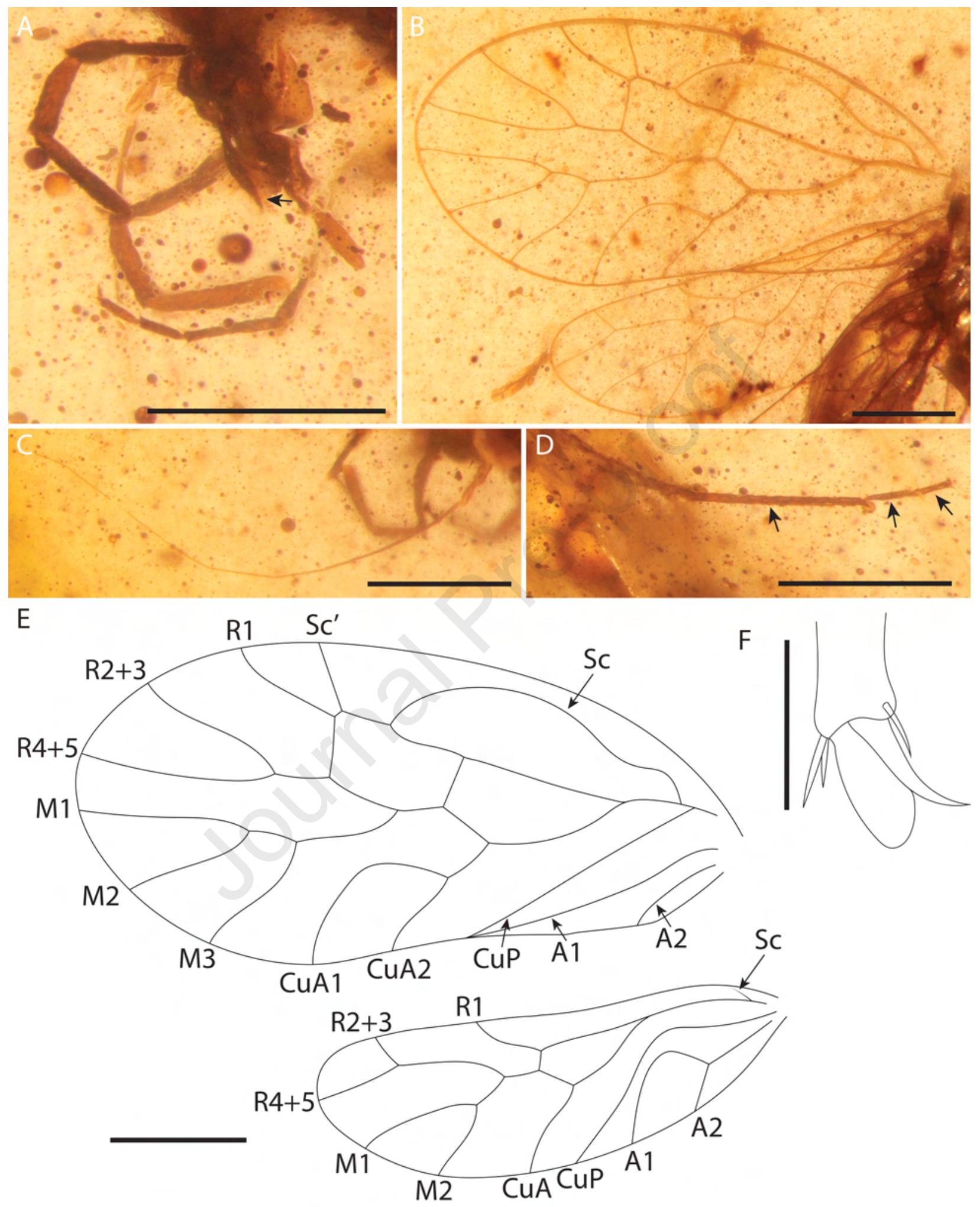




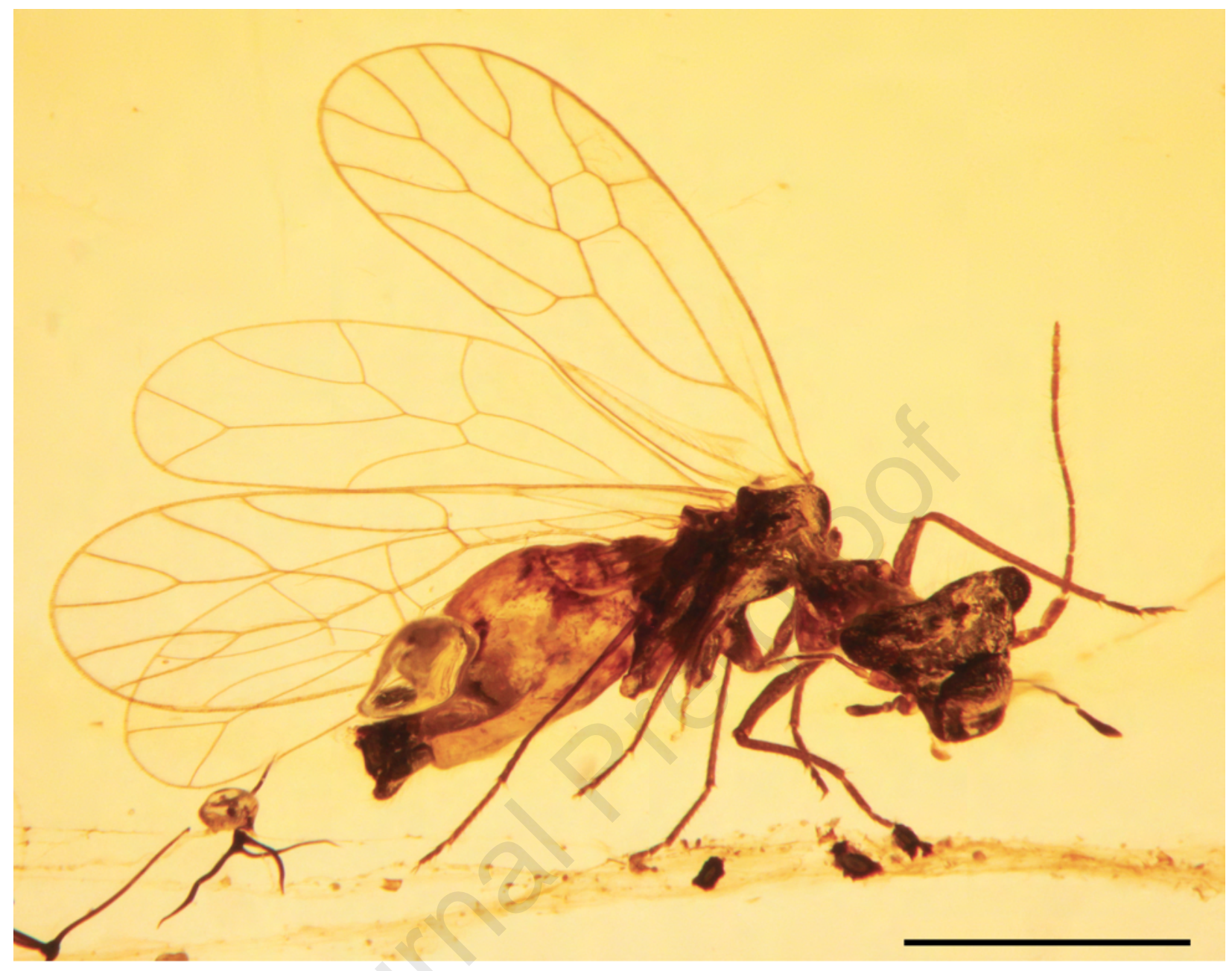



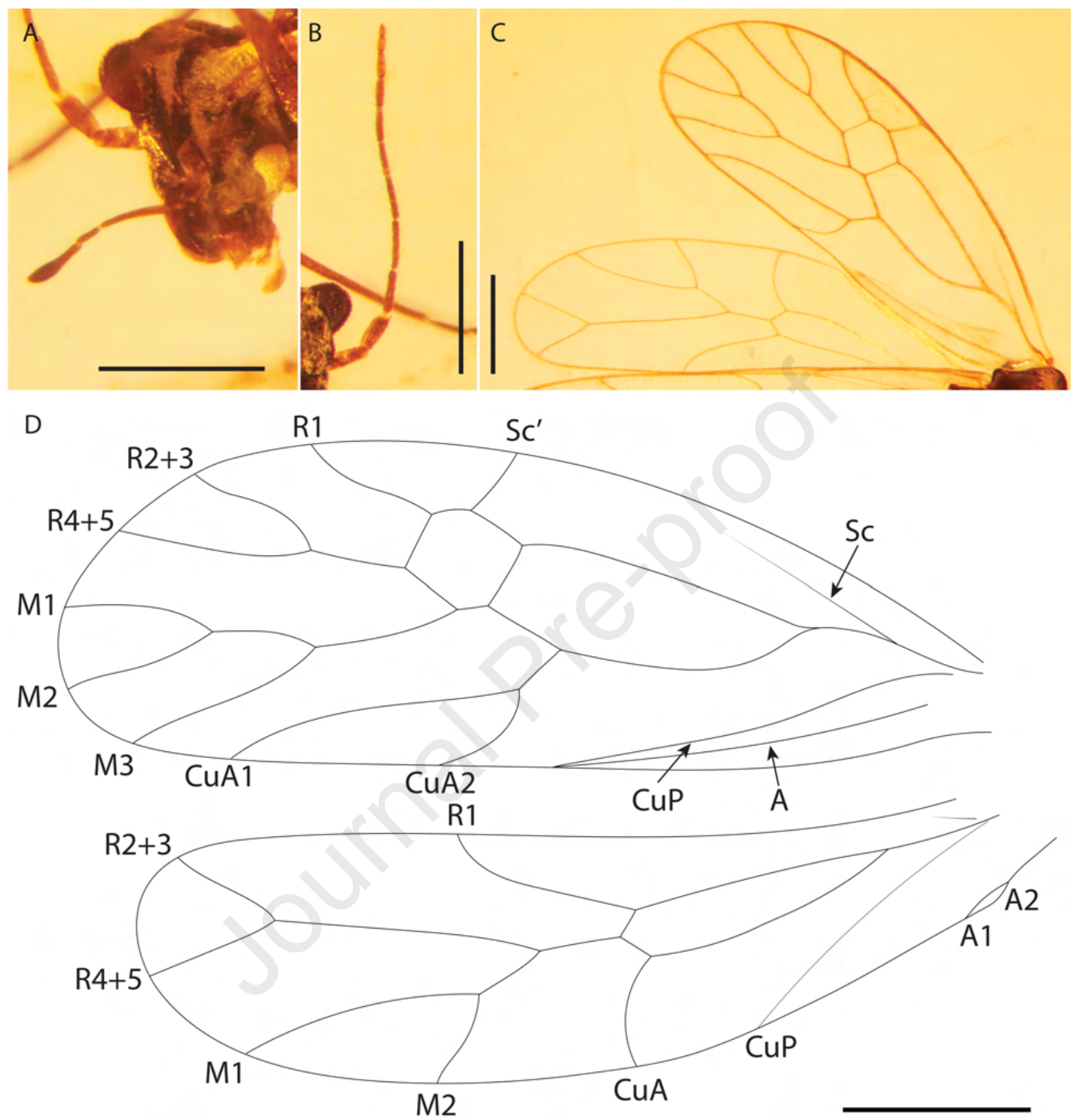


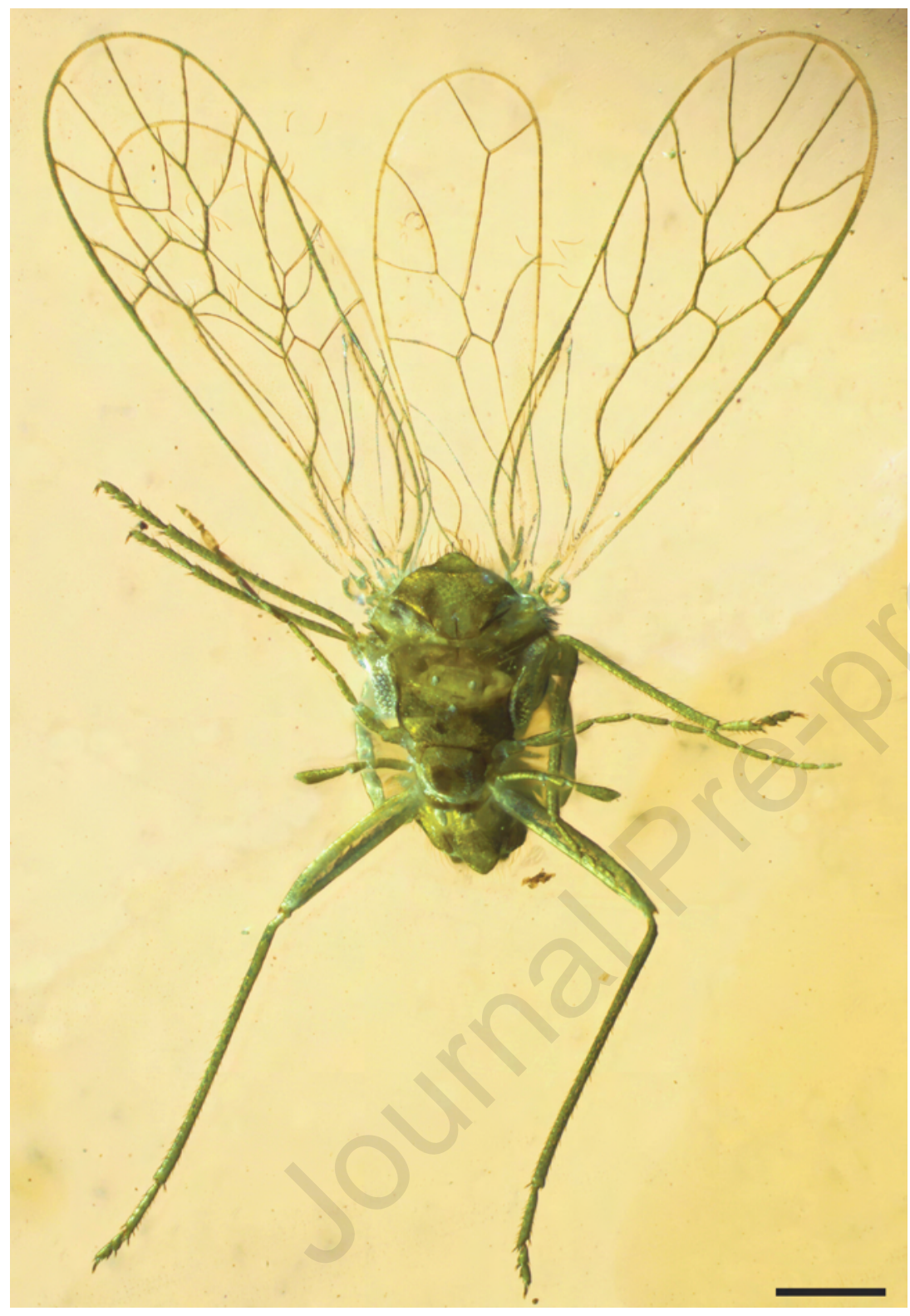




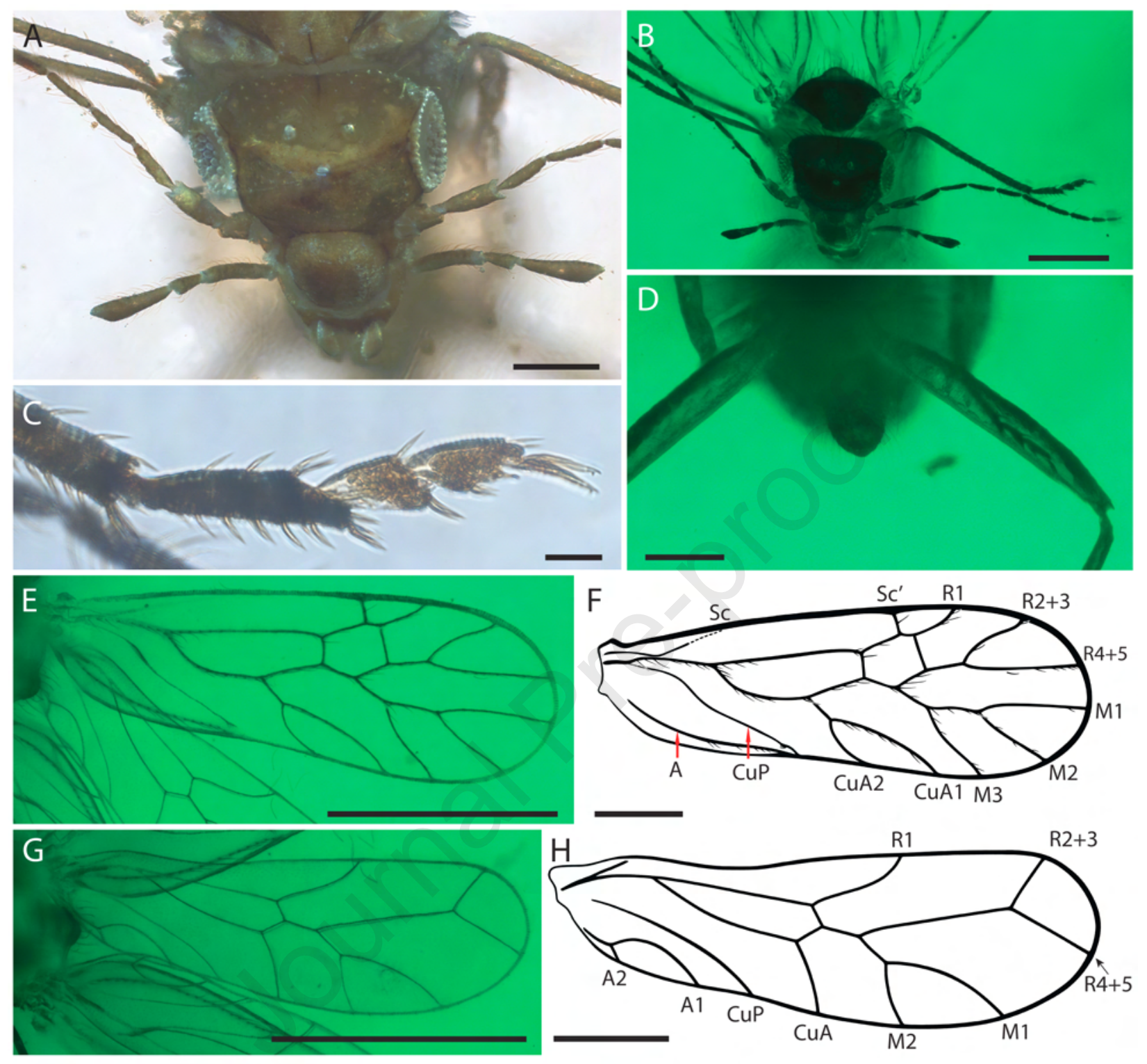


The authors declare that they have no known competing financial interests or personal relationships that could have appeared to influence the work reported in this paper. 